\title{
Interference in Working Memory is not Displacement nor Competition - It is Limited Destruction
}

\author{
Regina V. Ershova ${ }^{1}$, Eugen Tarnow ${ }^{2}$ \\ ${ }^{1}$ State University of Humanities and Social Studies \\ 30 Zelenaya St., Kolomna, 140410, Russian Federation \\ ${ }^{2}$ Avalon Business Systems, Inc. \\ 18-11 Radburn Road, Fair Lawn, NJ 07410, USA
}

\begin{abstract}
Free recall of 499 Russian college students was measured using the Tarnow Unchunkable Test (Tarnow, 2014) consisting of sets of 3 and 4 double digit items. Most students can remember 3 items but not 4 items and when the $4^{\text {th }}$ item is added the total recall decreases (Ershova \& Tarnow, 2016a).

Here we describe the interference that results when adding the fourth item. First, we find that interference affects the items differently, evidence that working memory does not consist of identical "slots"; primacy is found to be an important stabilizer. We model the four item experiment as a superposition of the three item result and a perfectly recalled $1^{\text {st }}$ or $4^{\text {th }}$ item and find that the $4^{\text {th }}$ position is affected 2.5 times as much as is the $1^{\text {st }}$ position. Second, contrary to the displacement/competition theory, recall correlations of the added item with the old items (apparently reported for the first time in a free recall experiment) are typically positive. Third these correlations decay exponentially with item-item presentation distance and are symmetric with respect to time reversal. Small negative recall correlations only appear for subjects with the smallest working memory capacities. Third, also contrary to displacement/competition theory, the fourth item is the least likely to be recalled, thus there is not much need for it to displace the other items.

This creates a paradox: while displaying the $\mathrm{N}+1$ item decreases the probability of recall of the $\mathrm{N}$ items, actually recalling the $\mathrm{N}+1$ item is positively correlated with recalling the other $\mathrm{N}$ items: the $\mathrm{N}+1$ item destroys some of the underlying memory system and then functions as a gauge of its own destruction.
\end{abstract}

Key words: interference, working memory, item-item correlations, serial position effect

\section{Introduction}

The brain contains a hundred billion neurons yet our working memory capacity (WMC) is limited to 3-7 items (Miller, 1956 and Cavanagh, 1972 and citations therein and thereof; a more recent work is Engle, 2002). If the reader attempts to remember four unrelated double digit integers (the Tarnow Unchunkable Test, TUT (Tarnow, 2014)), it is very probable that one or more of the previous integers vanish, no matter how hard the reader tries. This almost magical process of interference is the subject of this article.

Interference is a ubiquitous term of art. It can refer to task interference or memory interference or feature interference. It can refer to long term memory, short term memory or working memory. It can refer to the lessened ability of remembering items in a list if a previous list has been presented (Underwood, 1957) - the former list proactively 
interferes with the latter list or the latter list retroactively interferes with the former list. It can also be a reason of forgetting, in long term memory or short term memory, often in competition with decay (Underwood, 1957; Waugh and Norman, 1965; Portrat et al., 2008; Baddeley, 2002), for example researchers argue that perhaps learning one more item then simply displaces an old item (Waugh and Norman, 1965), while others argue that there is competition (Underwood, 1957) - suggesting that the two items are competing for the same "slot" - we will refer to this as "displacement/competition theory".

WMC is limited through interference (Waugh \& Norman, 1965), in particular when items are similar (Deutsch, 1970) but this limit can be further limited by interference from other effects (May et al., 1999; Kane \& Engle, 2000). Keppel \& Underwood (1962) proposed that proactive interference in short term memory should act similarly to proactive interference in long term memory and showed that proactive interference increased with the number of previous items.

In this article we will investigate interference during the first stage (Tarnow, 2015) of short term memory, working memory. In particular we will study the interference effects of adding the $4^{\text {th }}$ item to a list of three items, the $4^{\text {th }}$ item being equivalent to the straw that breaks the camel's back (perhaps a little similar to McCloskey \& Cohen, 1989). We will describe the interference item by item, apparently a first in the field.

We will be able to determine whether working memory consists of identical "slots" or not. If it does, interference from the $4^{\text {th }}$ item should affect the three previous items, supposedly kept in slots, the same way. We have previously provided evidence that working memory in the TUT consists of pointer collections rather than slots because the errors tend to preserve the base 10 position (Ershova \& Tarnow, 2017a). One pointer in the pointer collection strays but the other pointer remains is a better description of the experimental result than the content of a slot is discarded.

We will also determine how the probability of remembering the $4^{\text {th }}$ item correlates with the probability of remembering the previous items: if working memory consists of slots and the existing items are displaced by new items, the probability of remembering the $4^{\text {th }}$ item should negatively correlate with the probability of remembering the previous items.

This work is an outgrowth of a study of internet addiction (Ershova et al., 2016) in which we wanted to discern whether there were any relationships of internet addiction with short term memory. The results we found, just studying the memory component alone of up to 500 teaching college students, were surprising. First, the more items displayed, the fewer items the average students remembered. This also showed that the subjects could not manage their working memory (if they could, they would have tried to ignore the fourth item and performed better) and that $25 \%$ of subjects could not remember any items correctly at least in one of three 4 item tests and that the Pearson correlation between the 3 item and 4 item recalls was a relatively small $38 \%$ (Ershova \& Tarnow, 2016a). There were small differences between the genders: the possibility that the male/female ratio increases for low and high capacities was indicated, and we found that gender proportions in a field of study was a strong determinant of field WMC (Ershova \& Tarnow, 2017b); within each academic field there were no gender differences.

The academic fields of the students were found to account for about $5 \%(9 \%)$ of the variance in the average WMC for the 3-item (4-item) test. WMC increased in the order vocational, kindergarten $-5^{\text {th }}$ grade, chemistry, mathematics, philology, psychology, history, 
law, computer science, physics and sports. The future teaching level (kindergarten, grades $1-5$, grades $6-12$ and vocational) accounted for $2.2 \%(5.5 \%)$ of the variance in the 3 -item (4-item) test. There were larger differences for students of different faculties with the sports faculty having the highest capacity and we, in a sense, created a new field the study of WMC anthropology: we found that the university as an institution tended to admit students to fields with higher WMC (Ershova \& Tarnow, 2017c).

By analyzing the errors made in the TUT experiments, we found that errors in just the ones or tens digits were overrepresented implying that the brain organizes double digit numbers in a base- 10 fashion, and that the numerical factors 5 and 11 were underrepresented showing that additional base- 10 properties were used to limit possible errors. The base10 organization implies that there are separate memory maps for each position and that the items consist of pointer collections with pointers that can move primarily within these maps (Ershova \& Tarnow, 2017a). These pointers make errors that are old $80 \%$ of the times. We found working memory regularities which suggest that attention deficits and surpluses may be quantifiable in two parameters: the exponential increase in single errors as a function of the order of presentation and the number of consecutive double errors (Ershova \& Tarnow, 2016b).

The TUT was also used to evaluate 122 elderly subjects in a memory clinic (Tarnow, 2017). In this sample TUT was found to be gender and culture independent with small dependencies on age and years of education. The 3-item test (but not the 4-item test) selected diagnosed Alzheimer's disease but not amnestic MCI or non-amnestic MCI. On average, diagnosed Alzheimer's disease was correlated with a loss of 0.6 memory pointer collections (out of an average of 2.6 pointer collections).

\section{Method}

Sample. 480 Russian undergraduate teaching college students of the State University of Humanities and Social Studies and 19 law students participated in the study for extra credit (67\% females and $33 \%$ males, mean age 18.8 years). Each participant was tested individually in a quiet room. An experimenter was present throughout each session. One record was discarded - the student had only responded once out of a possible thirty times. We had no hypothesis about this research so we did not estimate the sample size needed in advance. The statistics reported includes the effect of the sample size. The sample size is relatively large (480 students each taking 3-6 tests).

Technique. The Tarnow Unchunkable Test (TUT) used in this study separates out the working memory (WM) component of free recall by using particular double-digit combinations which lack intra-item relationships (Tarnow, 2013). It does not contain any explicit WM operations. The TUT was given via the internet using client-based JavaScript to eliminate any network delays. The instructions and the memory items were displayed in the middle of the screen. Items were displayed for two seconds without pause (this limits rehearsal opportunity). The trials consisted of 3 or 4 items after which the subject was asked to enter each number remembered separately, press the keyboard enter button between each entry and repeat until all the numbers remembered had been entered. Pressing the enter button without any number was considered a "no entry". The next trial started immediately after the last entry or after a "no entry". There was no time limit for number entry. Each subject was given six three item trials and three four item trials 
in which the items are particular double-digit integers. This is in excess of the standard 2 trials for the digit span test in the Wechsler scales.

In the standard digit span test single digits are used and these are easily chunked: 5 and 7 becomes $57.5,7$ and 3 may become 573, or 5 and 73, or 57 and 3 or remain 5,7 and 3; thus the "span" is either one, two or three - ill defined. The advantage of the TUT over the common digit span test is its relative unchunkability: because double digits are more specific than single digits merging them into a four digit number is more difficult 65 and 23 does not easily chunk into 6523 . Thus the number of items is better defined, and there are no WM chunking operations taking place and it is free recall so that order memory is not required.

The statistical package used to calculate correlation matrixes and recall averages was RapidMiner 8. Curve fitting and plots were done using Excel 2007. The effects of the $4^{\text {th }}$ item were calculated using differences in averages.

\section{Results}

Separating out the effects of the $4^{\text {th }}$ item on recall. To define the interference effects using the 3-item and 4-item data, we consider the 4-item data as a sum of the 3-item data and a perfect recall of a single item (figure 1, upper panel) and that interference is what occurs as the two data are combined (figure 1, lower panel). There are two ways to add a single item and a three-item group and both constructs are displayed in figure 1.

The first finding is that interference occurs for all items but that it varies for all the items (17-60\% - see lower panel). In other words, working memory does not consist of equivalent slots, equally sensitive to interference. In the left, lower panel proactive interference from the first three items onto the fourth item is very large; in the right, lower panel proactive interference from the first item affects all subsequent items but not in a monotonous pattern and it is not the largest for the closest item. Retroactive interference in the left lower panel is largest for the items closest to the interfering fourth item and less for items further away; in the right lower panel the retroactive interference from items $2-4$ onto item 1 is relatively small. The ratio of interference on a single item if it is in the $4^{\text {th }}$ position versus if it is the $1^{\text {st }}$ position is 2.5 ; primacy provides stability.

To ensure that our result is not from averaging over many different individuals, we also considered two of the extremes. The results for just the highest performing and lowest performing faculties are shown in figure $2-$ there is no qualitative difference between the two though the interference is larger for the vocational faculty subjects.

Recall correlations. What is the underlying mechanism of this interference? If interference is due to displacement or competition, the new item and an old item would not be recalled at the same time. If we calculate the correlations of the outcomes of recalls of a model system with items A and B and the two items never occur at the same time (B either displaces A, or A remains and B is not recalled) the correlation between A and $\mathrm{B}$ is -1 . We find that, in contrast, there are no negative correlations (see figure 3 ). The correlations decrease with inter-item distance, the same for both 3 and 4 items, and decay approximately exponentially with a conveniently remembered 1 /e for each position. Surprisingly the correlations of the last item with the previous items is similar to the correlations of the first item with the consecutive items - the direction of time does not seem to be that important! 
Item 4 added to items 1-3

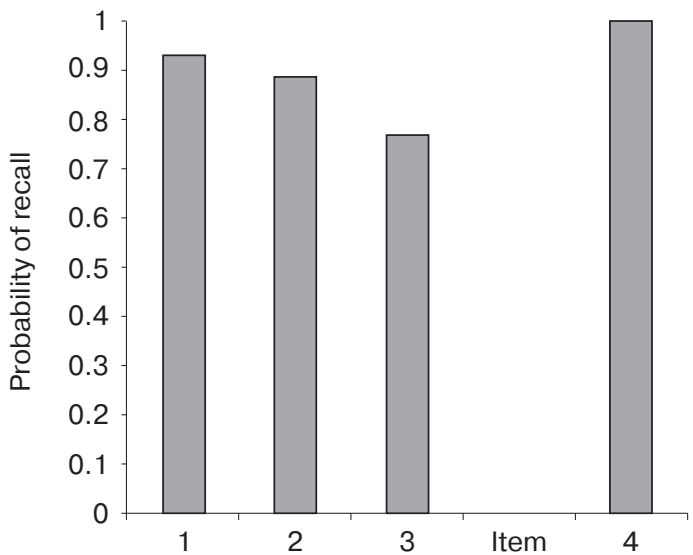

Item added at the end

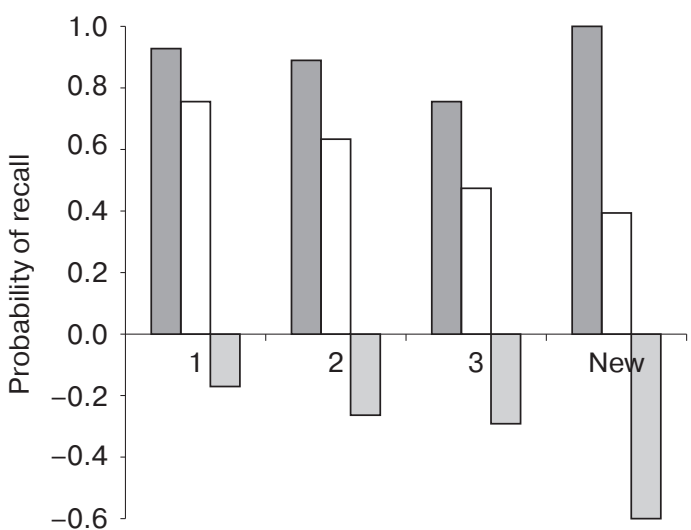

Item
Item 1 added to items $2-4$

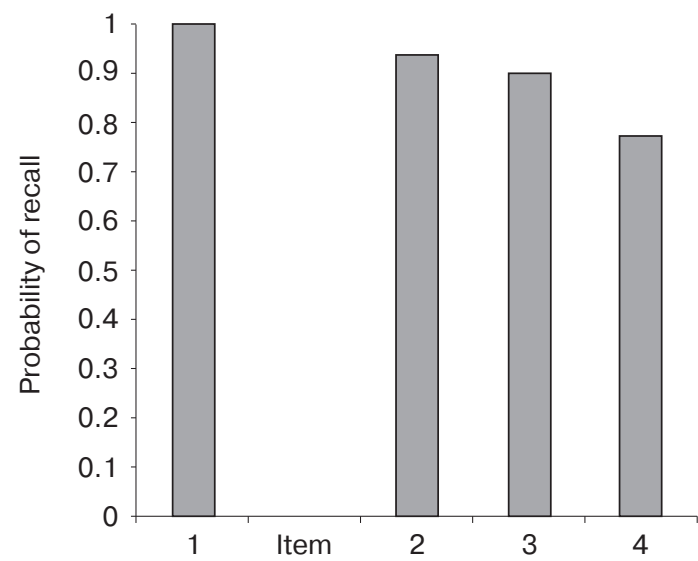

Item added at the beginning

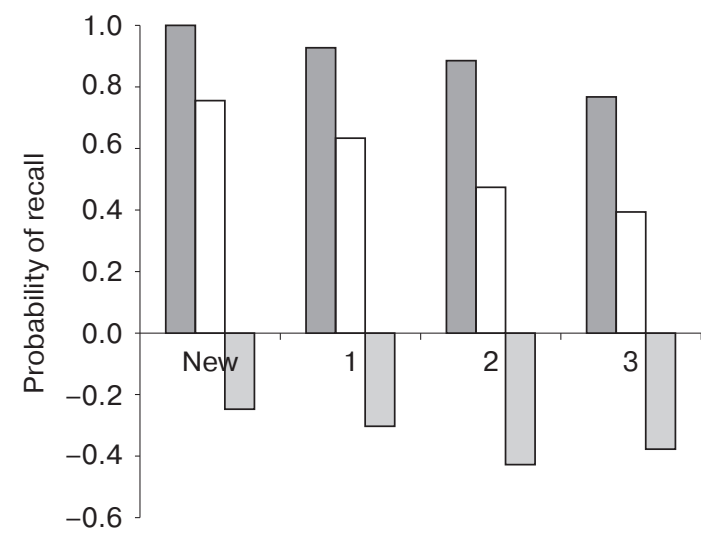

Item

\section{No interaction $\square$ Actual $\square$ Difference = Interference}

Figure 1. Interference calculated using either the $4^{\text {th }}$ or $1^{\text {st }}$ items as single items combined with the 3 -item probabilities from the 3-item experiment. Upper panel symbolizes the two separate ("no interaction") lists.

Lower panel the experimental data from the interacting lists 
Item added at the end

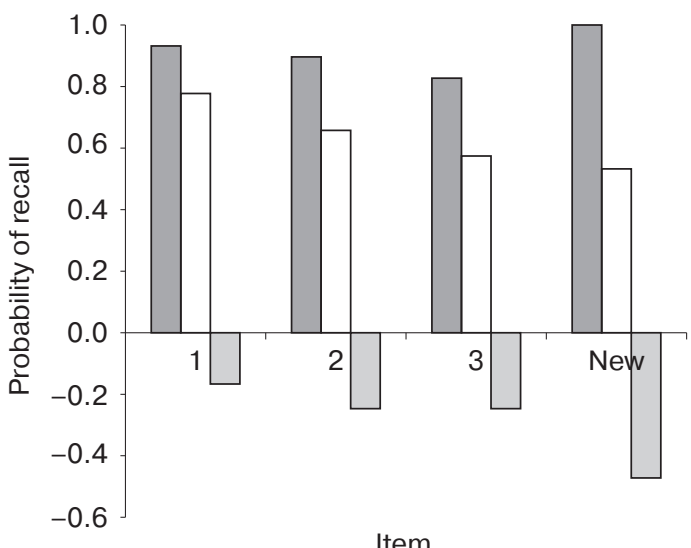

Item added at the end

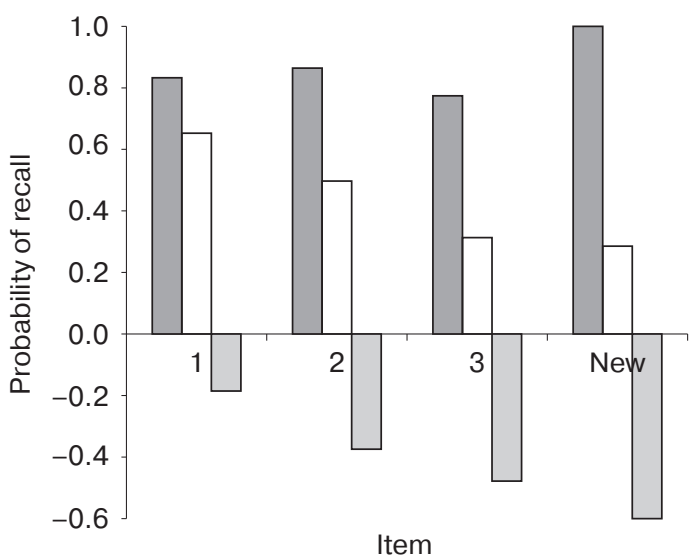

Item added at the beginning

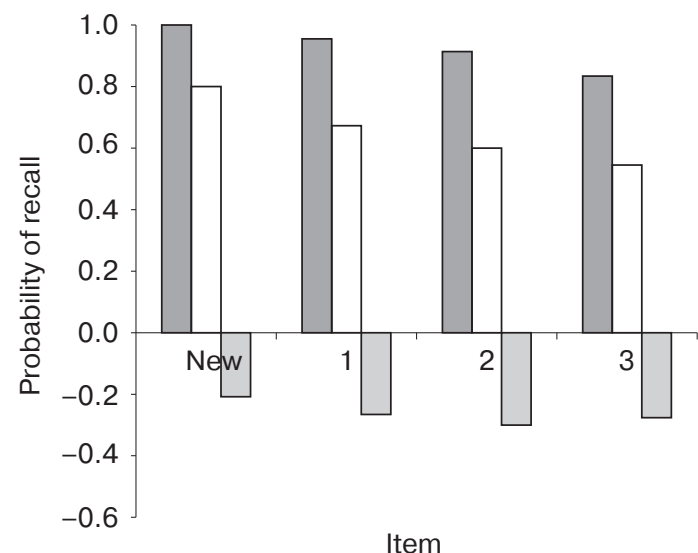

Item added at the beginning

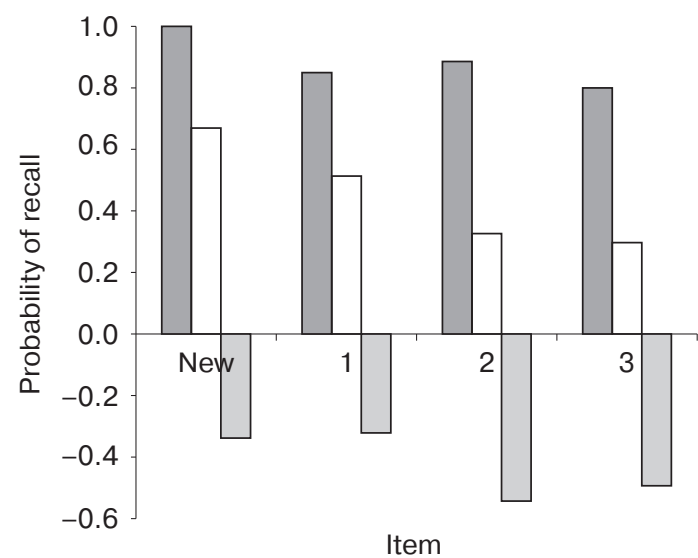

No interaction $\square$ Actual $\square$ Difference = Interference

Figure 2. Interference calculated using either the $4^{\text {th }}$ or $1^{\text {st }}$ items as single items combined with the 3 -item probabilities from the 3-item experiment. The upper panel includes subjects from the sports faculty and the lower panel includes subjects from the vocational faculty

The same results for the highest and lowest performing faculties are displayed in figure 4. The correlations decay more slowly for the sports faculty and more quickly for the vocational faculty subjects. For the latter there is a small negative correlation in the 4-item test and a zero correlation between the first and third items in the 3-item test.

Thus the interference effect from the display of the fourth item is a decreasing ability to support recall of any item though primacy offers some protection. The actual recall of the fourth item is not correlated with the displacement of other items or competition between items. Instead the recall of the fourth item is correlated with recall of the previous three items; and in effect functions as a gauge of its own destruction of the memories. 


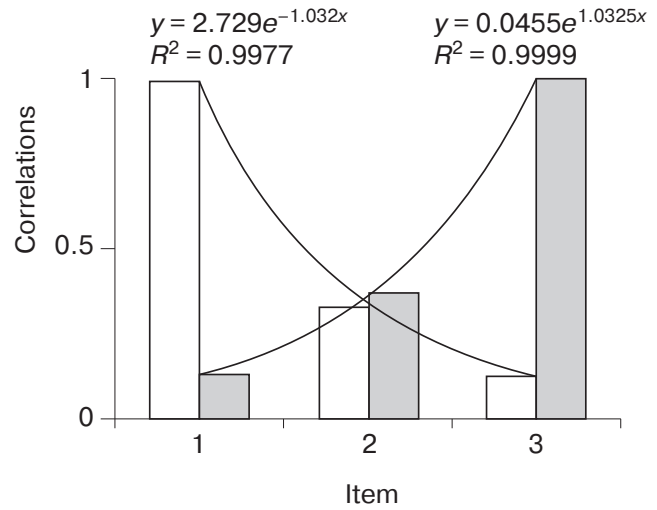

Item 1 correlations $\square$ Item 3 correlations

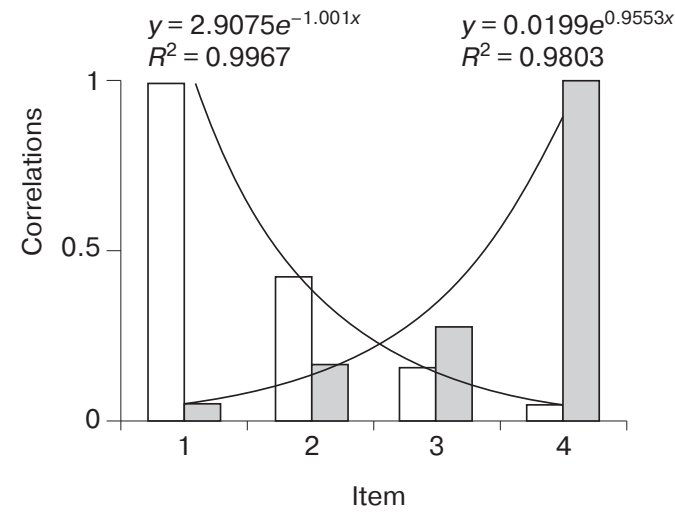

$\square$ Item 1 correlations $\square$ Item 4 correlations

Figure 3. Average correlations of item recall probabilities. Note that the correlations are not negative, as would be the case if the new item substituted for an old item. Neither are they 0 , rather they decay in an exponential fashion away from the probe item. The exponential decay is the same for the 3 -item and 4-item experiments and is symmetric with respect to time reversal

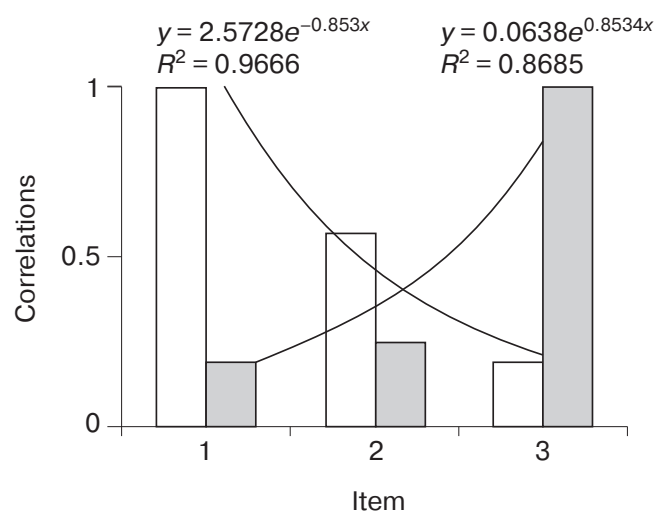

$\square$ Item 1 correlations $\square$ Item 3 correlations

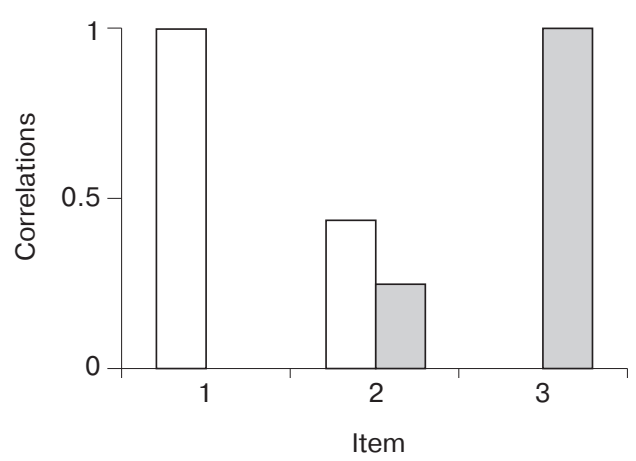

$\square$ Item 1 correlations $\square$ Item 3 correlations

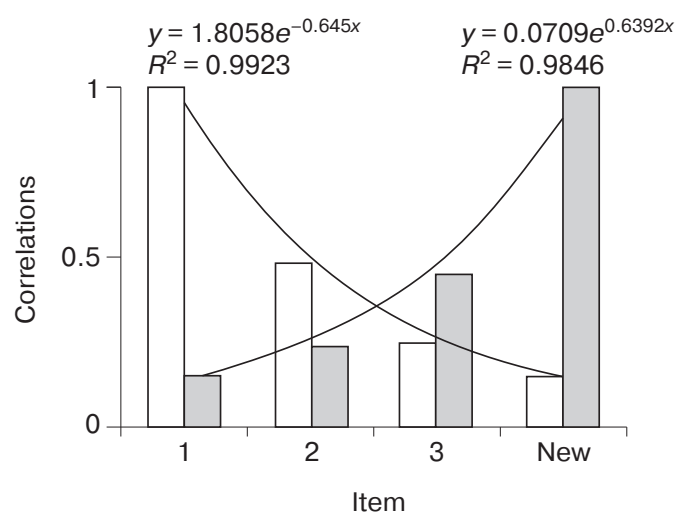

$\square$ Item 1 correlations $\square$ Item 4 correlations

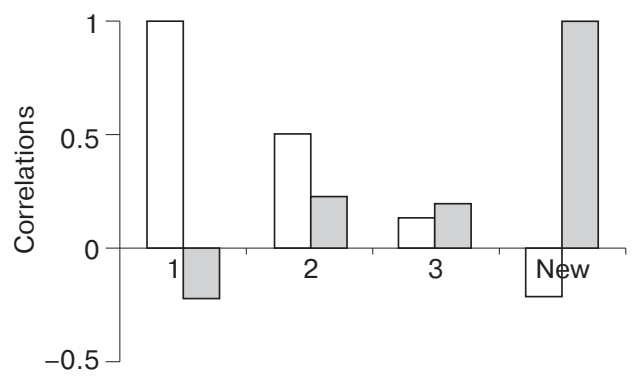

Item

Figure 4. Average correlations of item recall probabilities for high performing sports (upper panel) and low performing vocational (lower panel) students 


\section{Discussion}

We defined, apparently for the first time, the interference effects of an $\mathrm{N}+1$ list item: the $4^{\text {th }}$ item can be added at the end or at the beginning of the list and the interference effect on each item is the difference in recall with and without the $4^{\text {th }}$ item.

First, we found that primacy provides stability. If we consider the $1^{\text {st }}$ item as the new item it was the most likely to be recalled, if we consider the $4^{\text {th }}$ item as the new item it was the least likely to be recalled.

Previously reported TUT serial position curves (Ershova \& Tarnow, 2016a), suggested that interference by displacement was somewhat unlikely since the last item is the least recalled item (note: this absence of "recency" also occurs for short list immediate word free recall, see figure 1 in Ward et al, 2010). Here we went a step further and were able to prove that, for all but the lowest performing students, neither displacement nor competition occurs by examining the item-item correlations. For most students these correlations were positive, disproving displacement or competition mechanisms which should show negative correlations.

We have argued before that working memory slots do not exist - if they did they would have been common knowledge and named by now and, more particularly, errors in the TUT items show that there is overlap between the displayed items in memory - there are no isolated slots (Ershova \& Tarnow, 2016b; Ershova \& Tarnow, 2017a). In this article, by considering the recall differences between the 3 -item results and the 4 -item results we find that a more accurate description of the dynamics of working memory is that each display of an item lowers the probability of remembering the other items. Each displayed item causes a limited destruction (but not displacement nor competition) in working memory.

While displaying an item is correlated with lowered recalls for other items, the positive correlations show that recall of the item is typically correlated with higher recall for the other items. We interpret this result as recall of the item is indicative of a better functioning working memory. Surprisingly, the correlations were symmetric with respect to time reversal so as far as item-item correlations are concerned it does not matter which item was displayed first.

There is a current controversy whether visual working memory consists of slots (Zhang \& Luck, 2008; Luck \& Vogel, 2013) or a limited resource that can be shared between items in the visual scene (Bays \& Husain, 2008; Ma et al., 2014). There are two well defined experiments that argue for the opposing views. If one displays six squares of different colors and then displays just one of the squares slightly shifted, all six squares remain in memory but the precision of the shift declines (Bays \& Husan, 2008; for similar experiments see Alvarez \& Cavanagh, 2004; Schneegans \& Bays, 2016). If one, on the other hand, displays six squares of different colors and asks for the color of one of those squares, the subjects can only remember the color of three of those squares (Zhang \& Luck, 2008).

The TUT data show features of the data on both sides. Just like adding a square causes the precision of the displacement of the squares to worsen, the $4^{\text {th }}$ TUT item causes the probability of recall of the previous items to drop. But like adding a colored square does not increase the number of colored squares remembered, the $4^{\text {th }}$ TUT item on average does not increase the number of items recalled (it often decreases it). 
The TUT result is not covered by the theory of Fougnie et al (2012) in which working memory capacity is limited by "a stochastic process of degradation that plays out independently across memories" - in our experiments the items are displayed in a particular order and the degradation depends on the order of display and primacy provides stability.

It would be interesting to see whether recalling the color of a square is positively or negatively correlated with the probability of recalling a color of another square in the experiment of Zhang \& Luck (2008).

\section{Conclusions}

The current findings, that any item displayed causes limited destruction of working memory, and that a $4^{\text {th }}$ item actually lowers overall recall, may be important for textbook design (if working memory content eventually translates into long term memory, see Baddeley, 2003; working memory training does not seem to translate into a better long term memory, see Melby-Lervåg et al., 2016; the method of loci which expands the capacity is not in general use, also suggesting a tenuous connection between WMC and learning). Presumably textbook design needs to include ways to deal with a limited WMC and here we only add that textbook design should include some experimentation as to just how many items in lists should be included. Perhaps it would be better to include many short lists rather than a few long lists: one additional list item may actually remove rather than add information.

\section{References}

Alvarez, G. A., \& Cavanagh, P. (2004). The capacity of visual short-term memory is set both by visual information load and by number of objects. Psychological science, 15(2), 106-111. doi: 10.111/j.09637214.2004.01502006.x

Baddeley, A. (2003). Working memory: looking back and looking forward. Nature reviews neuroscience, 4(10), 829. doi: $10.1038 / \mathrm{nrn} 1201$

Baddeley, A. D. (2002). Is working memory still working? European psychologist, 7(2), 85. doi: 10.1027//1016-9040.7.2.85

Bays, P. M., \& Husain, M. (2008). Dynamic shifts of limited working memory resources in human vision. Science, 321(5890), 851-854. doi: 10.1126/science.1158023

Benedet, M. J., \& Alejandre, M. Á. (1998). TAVEC: test de aprendizaje verbal España-Complutense. Madrid: Tea.

Crowder, R. G. (2014). The interference theory of forgetting in long-term memory. In Principles of Learning and Memory (pp. 234-279). Psychology Press.

Deutsch, D. (1970). Tones and numbers: Specificity of interference in immediate memory. Science, 168(3939), 1604-1605. doi: 10.1126/science.168.3939.1604

Engle, R. W. (2002). Working memory capacity as executive attention. Current directions in psychological science, 11(1), 19-23. doi: 10.1111/1467-8721.00160

Ershova, R.V., \& Semina, T.M. (2016). The personal traits of internet-addicted students. In Digital society as a cultural and historical context of human development, 123-128. (In Russ.)

Ershova R.V., Semina T.M., Varchenko N.N., Gankin K.A., Novik V.P. (2016). The pupillometric predictor of internet-addiction. RUDN Journal of Psychology and Pedagogics, (1), 42-54. 
Ershova, R., \& Tarnow, E. (2016a). Working Memory Capacity Test Reveals Subjects Difficulties Managing Limited Capacity. RUDN Journal of Psychology and Pedagogics, (3), 14-19.

Ershova, R. V., Tarnow, E. (2016b). Characterization of Working Memory Singlet Errors. Penza psychological newsletter PSYCHOLOGY-NEWS.RU, (2), 121-136.

Ershova, R. V., Tarnow, E. (2017a). Working Memory Structure Revealed In Analysis Of Recall Errors. RUDN Journal of Psychology and Pedagogics, 14(1), 17-25.

Ershova, R., Tarnow, E. (2017b). Working memory capacity \& gender. In Applied Psychology in Service of the Developing Person (pp. 259-266).

Ershova, R., \& Tarnow, E. (2017c). Working Memory Capacities Differ by Academic Field: Sports Teachers on Top. URL: https://www.amazon.com/dp/B07DN5823V

Fougnie, D., Suchow, J. W., \& Alvarez, G. A. (2012). Variability in the quality of visual working memory. Nature communications, (3), 1229.

Kane, M. J., \& Engle, R. W. (2000). Working-memory capacity, proactive interference, and divided attention: limits on long-term memory retrieval. Journal of Experimental Psychology: Learning, Memory, and Cognition, 26(2), 336.

Keppel, G., \& Underwood, B. J. (1962). Proactive inhibition in short-term retention of single items. Journal of verbal learning and verbal behavior, 1(3), 153-161.

Lewis, R. L. (1996). Interference in short-term memory: The magical number two (or three) in sentence processing. Journal of Psycholinguistic Research, 25(1), 93-115.

Luck, S. J., \& Vogel, E. K. (2013). Visual working memory capacity: from psychophysics and neurobiology to individual differences. Trends in cognitive sciences, 17(8), 391-400. doi: 10.1016/j.tics.2013.06.006

Ma, W. J., Husain, M., \& Bays, P. M. (2014). Changing concepts of working memory. Nature neuroscience, 17(3), 347. doi: 10.1038/nn.3655

Massaro, D. W. (1970). Retroactive interference in short-term recognition memory for pitch. Journal of Experimental Psychology, 83(1, Pt. 1), 32.

Mato-Abad, V., Jiménez, I., García-Vázquez, R., Aldrey, J., Rivero, D., Cacabelos, P., RodríguezYáñez, S. (2018). Using Artificial Neural Networks for Identifying Patients with Mild Cognitive Impairment Associated with Depression Using Neuropsychological Test Features. Applied Sciences, 8(9), 1629. doi: 10.3390/app8091629

May, C. P., Hasher, L., \& Kane, M. J. (1999). The role of interference in memory span. Memory \& cognition, 27(5), 759-767. doi: 10.3758/BF03198529

McCloskey, M., \& Cohen, N. J. (1989). Catastrophic interference in connectionist networks: The sequential learning problem. Psychology of learning and motivation, 24, 109-165.

Melby-Lervåg, M., Redick, T. S., \& Hulme, C. (2016). Working memory training does not improve performance on measures of intelligence or other measures of "far transfer" evidence from a metaanalytic review. Perspectives on Psychological Science, 11(4), 512-534. doi: 10.1177/1745691616635612

Miller, G. A. (1956). The magical number seven, plus or minus two: Some limits on our capacity for processing information. Psychological review, 63(2), 81.

Portrat, S., Barrouillet, P., \& Camos, V. (2008). Time-related decay or interference-based forgetting in working memory? Journal of experimental psychology: Learning, memory, and cognition, 34(6), 1561. doi: $10.1037 / \mathrm{a} 0013356$

Schneegans, S., \& Bays, P. M. (2016). No fixed item limit in visuospatial working memory. Cortex, 83, 181-193. doi: 10.1016/j.cortex.2016.07.021

Tarnow, E. (2014). U.S. Patent Application No. 13/782,011. 
Tarnow, E. (2017). Preliminary Evidence: Diagnosed Alzheimer's Disease but not MCI Affects Working Memory: 0.6 of 2.6 Memory Pointers Lost. Journal Alzheimers Dis Parkinsonism, 7(315), 21610460. doi: $10.4172 / 2161-0460.1000315$

Underwood, B. J. (1957). Interference and forgetting. Psychological review, 64(1), 49.

Ward, G., Tan, L., \& Grenfell-Essam, R. (2010). Examining the relationship between free recall and immediate serial recall: the effects of list length and output order. Journal of Experimental Psychology: Learning, Memory, and Cognition, 36(5), 1207. doi: 10.1037/a0020122

Waugh, N. C., \& Norman, D. A. (1965). Primary memory. Psychological review, 72(2), 89. doi: 10.1037/ h0021797

Zhang, W., \& Luck, S. J. (2008). Discrete fixed-resolution representations in visual working memory. Nature, 453(7192), 233. doi: 10.1038/nature06860

(C) Ershova R.V., Tarnow E., 2018

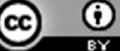

This work is licensed under a Creative Commons Attribution 4.0 International License

Article history:

Received: 16 January 2018

Revised: 10 October 2018

Accepted: 15 October 2018

\title{
For citation:
}

Ershova, R.V., \& Tarnow, E. (2018). Interference in Working Memory is not Displacement nor Competition - It is Limited Destruction. RUDN Journal of Psychology and Pedagogics, 15(4), 488-499. doi: 10.22363/2313-1683-2018-15-4-488-499

\section{Bio Notes:}

Regina V. Ershova - Doctor Sc. of Psychology, Full Professor, Professor of Department of Psychology of State University of Humanities and Social Studies (Kolomna, Russia). E-mail: erchovareg@mail.ru

Eugen Tarnow - Ph.D. in Physics, Data Scientist \& Director of Consulting, Avalon Business Systems, Inc (New York, USA). E-mail: ETarnow@avabiz.com

\section{Механизм разрушения как причина интерференции в рабочей памяти}

\author{
P.В. Ершова ${ }^{1}$, Ю. Тарноу \\ ${ }^{1}$ Государственный социально-гуманитарный университет \\ Российская Федерация, 140410, Коломна, ул. Зеленая, 30 \\ ${ }^{2}$ Авалон Бизнес Системс, Инк. \\ 18-11 Редбурн Роад, Фейр Лоун, Нью-Джерси 07410, США
}

Свободное припоминание 499 российских студентов было измерено с использованием Tarnow Unchunkable Test, состоящего из наборов из 3 и 4 двузначных чисел. Большинство студентов могут воспроизвести 3 числа, при добавлении 4-го числа количество припоминаемых элементов снижается. В статье описываются помехи воспроизведения, которые возни- 
кают при добавлении в запоминаемый ряд четвертого элемента. Было обнаружено, что интерференция влияет на предъявляемые к запоминанию элементы по-разному, это означает, что рабочая память не состоит из одинаковых «слотов». Эффект порядка предъявления выступает важным фактором при припоминании. В рамках экспериментальных проб (при добавлении в пробы четвертого элемента как суперпозиции к трехэлементным пробам) было доказано, что число, предъявляемое на четвертой позиции, в 2,5 раза чаще затрагивается интерференцией, чем число, стоящее на первом месте в предъявляемом ряду. Вопреки теории замещения/конкуренции ответов (отзывов), корреляции добавленного и ранее предъявленных элементов являются не отрицательными, а положительными. Причем эти корреляции экспоненциально убывают в зависимости от позиции элемента в пробе и являются симметричными относительно времени предъявления. Слабые отрицательные корреляции отзыва обнаружены только у лиц с наименьшим объемом рабочей памяти. Несмотря на теорию смещения/конкуренции ответов, четвертый элемент наименее вероятен для припоминания, поэтому вероятность того, что он вытеснит ранее предъявленные элементы крайне мала. Таким образом, на лицо парадокс: добавление элемента $\mathrm{N}+1$ снижает вероятность припоминания $\mathrm{N}$ элементов, в то же время возможность припоминания элемента $\mathrm{N}+1$ положительно коррелирует с припоминанием других $\mathrm{N}$ элементов. Это означает, что элемент $\mathrm{N}+1$ разрушает часть предшествующих элементов памяти и далее выступает как причина собственного разрушения.

Ключевые слова: интерференция, рабочая память, корреляции элементов, эффект порядка предъявления

\section{История статьи:}

Поступила в редакцию: 16 января 2018 г.

Принята к печати: 15 октября 2018 г.

\section{Для цитирования:}

Ershova R.V., Tarnow E. Interference in Working Memory is not Displacement nor Competition It is Limited Destruction (Механизм разрушения как причина интерференции в рабочей памяти) // Вестник Российского университета дружбы народов. Серия: Психология и педагогика. 2018. Т. 15. № 4. С. 488-499. doi: 10.22363/2313-1683-2018-15-4-488-499

\section{Сведения об авторах:}

Ершова Регина Вячеславовна - доктор психологических наук, профессор, профессор кафедры психологии Государственного социально-гуманитарного университета (Коломна, Россия). E-mail: erchovareg@mail.ru

Тарноу Юджин - Ph.D., независимый исследователь, директор по консалтингу Авалон Бизнес Системс, Инк. (Нью-Йорк, США). Е-mail: ETarnow@avabiz.com 